CLINICAL STUDY

\title{
Persistent disease after surgery for primary hyperparathyroidism: the long-term outcome
}

\author{
Gunilla Hedbäck and Anders Odén ${ }^{1}$ \\ Departments of Surgery and ${ }^{1}$ Mathematics and Statistics, Sahlgrenska University Hospital, Göteborg, Sweden \\ (Correspondence should be addressed to G Hedbäck, Department of Surgery, Sahlgrenska Sjukhuset, SE-413 45 Göteborg, Sweden; \\ Email: g.hedback@home.se)
}

\begin{abstract}
Objective: Nineteen patients with persistent primary hyperparathyroidism were investigated to evaluate their clinical and laboratory status a long time after treatment was ended. The risk of persistent disease and need for extensive surgery for cure, i.e. more than two neck operations, or mediastinal exploration, was also evaluated.

Design: The medical records of 896 consecutive patients operated on for primary hyperparathyroidism were scrutinised at follow-up, a mean of 10.3 years after surgery. Data on state of health, medication, bone fractures and other diagnoses were collected by use of a questionnaire. There were 600 patients still alive, among whom 13 had persistent disease and they were compared with 509 patients who were cured and without any suspicion of recurrent disease, according to laboratory examination. Results: Serum calcium and creatinine values had with few exceptions remained stable over the years. In five patients, serum calcium levels were within the normal range at follow-up. Still, all 19 patients were considered hyperparathyroid. They had substantial cardiovascular morbidity, and their state of health was not as good as that of the patients who were surgically cured. After one operation, 5.5\% (95\% confidence interval (CI) 4.0-7.2\%) had persistent disease, and $2.1 \%$ after reoperation. Extensive surgery for cure was performed in $2 \%$ of the patients (95\% CI $1.1-3.2 \%$ ).

Conclusions: We found that the state of health was significantly better for patients with cured primary hyperparathyroidism than for patients with persistent disease, but serious deterioration of laboratory values was uncommon. The result of the present study supports surgical treatment.
\end{abstract}

European Journal of Endocrinology 150 19-25

\section{Introduction}

Surgery is the effective treatment for primary hyperparathyroidism. However, several patients have been reported to get on rather well without surgery $(1-6)$, although this could not have been predicted. At present the arguments for treatment of primary hyperparathyroidism appear weighty even in asymptomatic disease. The success rate of parathyroid surgery is high, but not $100 \%$. The aim of this paper was to find out what happened in the long run to the few patients who were not cured in spite of surgery, and also how frequently extensive surgery was necessary for cure.

\section{Patients and methods}

The medical records of all patients operated on for primary hyperparathyroidism at Sahlgrenska Hospital in Göteborg in the years 1953-1982 were scrutinised $(n=896)$. Generally, bilateral neck exploration had been performed, and hyperparathyroidism was histopathologically verified in all cases. In 1986-1987 a long-term follow-up was performed to determine mortality (7) and also the patients' laboratory data and medical status (8) after surgery for primary hyperparathyroidism. Because of different follow-up procedures three groups of patients were defined: group I was patients followed up at Sahlgrenska Hospital; group II was patients followed up outside Göteborg; and group III included the patients who were deceased. The 600 patients alive were contacted by letter containing an invitation to take part in a follow-up programme including a questionnaire, laboratory tests and blood pressure measurement. For the deceased, group III, medical records from the period after the operation at Sahlgrenska Hospital were searched for. Follow-up values of serum calcium concentration were obtained in 787 patients $(88 \%)$, with a mean follow-up time of 10.03 years (S.D. 6.0) (8). The serum calcium and creatinine levels were determined in all patients, but for those living in Göteborg and examined at Sahlgrenska 
Hospital, group I, ionised serum calcium and parathyroid hormone levels were also taken. Reference limits varied slightly between laboratories, but the upper reference limit of total serum calcium concentration did not. The reference limits of the laboratory of Sahlgrenska Hospital of total serum calcium were $2.20-2.60 \mathrm{mmol} / \mathrm{l}$, of ionised serum calcium $1.18-$ $1.31 \mathrm{mmol} / \mathrm{l}$, of serum parathyroid hormone $10-$ $65 \mathrm{ng} / \mathrm{l}$ (IRMA), or $<9.6 \mathrm{pmol} / \mathrm{l}$ (RIA), and of serum creatinine $<120 \mu \mathrm{mol} / \mathrm{l}$ for male and $<110 \mu \mathrm{mol} / \mathrm{l}$ for female (8).

Cure after parathyroid surgery had been defined as serum calcium concentration $<2.55 \mathrm{mmol} / \mathrm{l}$ during the first postoperative year (7). According to the medical records kept until the end of 1982 there were 27 patients out of 896 who with this definition were considered to have persistent disease (7). Two of these patients died postoperatively, one in 1962 within $24 \mathrm{~h}$ with cardiac arrest and acute haemorrhagic pancreatitis, the other in 1965 after 10 days with duodenal ulcer disease and acute uraemia, both with severe hypercalcaemia. The post-mortem examination of the latter revealed a myeloma in a lumbar vertebra to have caused her persistent hypercalcaemia instead of persistent hyperparathyroidism. Two additional patients were not found at scrutiny to have had true persistent disease. Four patients were surgically cured in 1983 and 1984. Nineteen patients were left with persistent disease: three patients had declined further surgery after their second unsuccessful operation. The remaining 16 patients were left without further surgery as they were considered to have only mild serum calcium elevations after their primary surgery, 2.44$2.70 \mathrm{mmol} / \mathrm{l}$ at discharge, and 12 of them had gained a substantial decrease. After the first postoperative year there was no regular routine for check-ups. Unfortunately serum calcium determinations taken at the out-patient department were differently documented and therefore in a few cases lost to the present followup. The situation at follow-up was evaluated for each patient, the mode of surgery, the serum calcium and creatinine levels, and the history after parathyroid surgery. The risk for the need for extensive surgery for cure was estimated, and also the risk of persistent disease after surgery for primary hyperparathyroidism, with and without reoperations considered, and 95\% confidence intervals (CIs) were calculated exactly by use of the binomial distribution (9).

At follow-up the patients alive with persistent hyperparathyroidism were compared with the patients alive who were surgically cured and without any suspicion of recurrent disease as evaluated by their follow-up levels of serum calcium and parathyroid hormone. In the questionnaire it was asked whether the patient had been treated for bone fracture during the followup period, and if so, in what year, and which bone had been injured. It was asked about current medication, which was answered either by marking given alternatives, or by writing the name of the drug, or both. There was also a section in which the patients were asked to evaluate their state of health by marking the suitable answers $(\mathrm{a}-\mathrm{e})$ to five simple questions: (a) I am in excellent health (yes/no); (b) I am concerned about some kind of disorder/worry/anxiety $($ no $=0$, slightly $=1, \quad$ moderately $=2, \quad$ substantially $=3$ ); (c) my condition/discomfort/illness affects my everyday life $($ no $=0$, slightly $=1$, moderately $=2$, substantially = 3); (d) I need frequent medical care or am under investigation because of a serious situation (yes/no); and (e) I am in a nursing home permanently (yes/no). The filling in of the questionnaire was generally checked by the nurse who took the follow-up blood samples.

A two-tailed $t$-test was used for comparison of mean age between the two patient groups studied. Fisher's exact test was used for comparison of proportions in these two groups, and also for the 'yes/no' answers. A test for trend in contingency tables (10) was used when comparing the state of health in the two groups, as for the graded answers in b and c, described above. All $P$ values given are two-tailed.

\section{Results}

Primarily, after one operation, persistent hypercalcaemia because of hyperparathyroidism occurred in 49 out of 896 patients, $5.47 \%$, shown in Table 1 . Thirtytwo underwent further parathyroid surgery, and 29 out of 49 became surgically cured, 20 with multiplegland disease, and nine with single-gland disease, the latter generally with an unusual site of the pathological gland, or a fifth gland. One patient had an adenoma inside the thyroid capsule. Another had instead the problem of diseased parathyroid tissue being implanted in the neck muscles, which proved to be very difficult to remove. Mediastinal exploration was performed in 13 patients, and in 12 of them the pathological parathyroid gland was found in the mediastinum. Extensive surgery, defined as more than two neck explorations, or mediastinal exploration, was performed in 18 patients. We found 5.5\% risk of having persistent hyperparathyroidism after one operation, with 95\% CI 4.0-7.2\%. If reoperations were considered, 19 out of 896 patients

Table 1 The events of 49 patients who had persistent primary hyperparathyroidism after their primary neck operation.

\begin{tabular}{lc}
\hline & No. of patients \\
\hline Died within 24h & 1 \\
Left with persistent disease & 16 \\
Declined reoperation & 3 \\
Normocalcaemic after two operations & 19 \\
Normocalcaemic after three operations & 7 \\
Normocalcaemic after four operations & 2 \\
Normocalcaemic after five operations & 1 \\
Total & 49 \\
\hline
\end{tabular}


had persistent disease, and the risk was $2.1 \%$, with 95\% CI 1.2-3.3\%. The risk of undergoing extensive surgery because of primary hyperparathyroidism at our clinic during this period was $2.0 \%$ with $95 \% \mathrm{CI}$ $1.1-3.2 \%$.

The 19 patients with persistent disease, four men and 15 women, were numbered according to year of surgery and are shown in Table 2 . It shows their preoperative peak serum calcium level, which was the mean of the two highest values registered, their level at discharge after surgery, and the serum calcium level(s) thereafter. It also shows the mode of surgery performed, and who were operated on for hyperparathyroidism more than once.

Table 3 shows the follow-up data of the 19 patients with persistent disease, including a summary of their medical situation. Mean age at follow-up was 70.6 years (S.D. 7.97), and mean follow-up time for the deceased was 3.6 years, and for the 13 patients alive a mean 10.3 years, range $4.2-21.1$ years. There were nine patients of group I, four with increased parathyroid hormone levels, and five with high hormone levels in relation to their serum calcium concentration, verifying hyperparathyroidism being the cause of hypercalcaemia. Such verification was available in only one of four patients of group II, and in one of six patients of group III. In spite of five patients having all follow-up serum calcium determinations within normal values, persistent hyperparathyroidism was still the probable diagnosis in these cases. They all had persistent hypercalcaemia after surgery, for which no other reason had been found. Fourteen patients had normal serum creatinine values at follow-up, two had values at the upper reference limit, and three had slight elevations $(125-140 \mu \mathrm{mol} / \mathrm{l})$. Thirteen patients had treatment for hypertension at surgery for hyperparathyroidism, and 17 had hypertension at followup. Cardiovascular disease, hypertension excepted, occurred in six patients at surgery and in 15 at follow-up.

The 13 patients alive at follow-up are shown in Table 4, with their own evaluation of their state of health, and also their history of bone fractures and cardiovascular disease. Four of the 13 patients alive with persistent disease had had fractures during the followup period $(30.8 \%)$, and 74 patients of the 509 with cured hyperparathyroidism (14.5\%), although this difference was not significant. There appeared to be a trend towards a higher rate of anxiety among the patients with persistent disease $(P=0.076)$, and the degree of discomfort and illness was significantly worse for the patients with persistent disease $(P<0.01)$, as was the occurrence of cardiovascular disease and/or hypertension $(P<05)$. Mean age of the 13 patients was higher, 70.3 years (S.D. 9.5), as compared with that of the cured patients, 65.7 years (S.D. 11.8), although this difference was not significant $(P=0.164)$. Mean follow-up time was 10.3 years (S.D.
5.4) for the former, and 11.3 years (S.D. 5.5) for the latter, and mean preoperative peak serum calcium level was $2.83 \mathrm{mmol} / \mathrm{l}$ (S.D. 0.14 ) and $2.88 \mathrm{mmol} / \mathrm{l}$ (S.D. 0.30) respectively.

\section{Discussion}

At long-term follow-up of 19 patients with persistent hyperparathyroidism, hypercalcaemia had with few exceptions kept stable and the serum calcium level was in most cases only marginally elevated. Only 16 out of 36 total serum calcium determinations performed at follow-up were elevated, and only two patients had both of the taken values increased. Besides these two, only three patients had one value above $2.75 \mathrm{mmol} / \mathrm{l}$. There was no substantial progression of renal impairment, as evaluated by the serum creatinine values. But we could also observe that the health descriptions of these patients were not at all satisfying. They had substantial cardiovascular morbidity, as was previously shown to be part of the hyperparathyroid condition (11).

Six out of 19 patients with persistent disease died 2.2-11.8 years after surgery for primary hyperparathyroidism at the mean age of 74.8 years (S.D. 6.76). They all had cardiovascular illness and/or hypertension, which was also their main cause of death with one possible exception: patient no. 1 who fell because of a cerebral haemorrhage and got a skull fracture and epidural bleeding as well. They also appeared to suffer from symptoms considered to be related to hyperparathyroidism.

It was reported that untreated or persistent hyperparathyroidism is a rather stable condition without progressive increase of serum calcium levels $(2-6)$, and compatible with long survival and lack of demonstrable deleterious effects on kidney and bone (4). This was just partly in agreement with our findings; long survival is a matter of definition. Our patients were too few for strict evaluation of survival, but 5 years below average length of life might not be 'long survival'. Furthermore, there appeared to be a negative effect on bone among the patients with persistent disease, their bone fracture frequency being doubled, but this difference was not significant. We found instead a significantly greater share of patients with persistent disease to have hypertension and/or cardiovascular disease. The conclusions in previous reports were divergent between recommending surgical treatment and conservative followup $(1-6)$. It seems as if the lack of change in serum calcium and creatinine values over time was generally the main argument not to recommend surgery in this debate $(2-4,12)$. These laboratory tests are easily measured but give only limited clinical information. A tendency towards high cardiovascular morbidity occurring in hyperparathyroidism was noted by Palmér et al. (12), and towards illness of various kinds by Corlew 
Table 2 Serum calcium levels $(\mathrm{Ca} / \mathrm{s})(\mathrm{mmol} / 1)$ of 19 patients before and after surgery for primary hyperparathyroidism, serum calcium decrease after surgery, and values taken thereafter, and at follow-up. The number of excised (exc) parathyroid glands (Pth), and number of parathyroid gland biopsies (b) out of the number macroscopically identified parathyroid glands are shown. Opx2 means operated on twice; Impl means excision of implanted parathyroid tissue; Thyr- $\mathrm{x}=$ thyroidectomy; $\mathrm{H}$-thyr- $\mathrm{x}=$ hemithyroidectomy; $\mathrm{Ad}=$ parathyroid adenoma; $\mathrm{Hpl}=$ Parathyroid hyperplasia. Group I was patients followed up in Göteborg, and group II outside Göteborg. Group III were patients deceased at

follow-up.

\begin{tabular}{|c|c|c|c|c|c|c|c|c|c|c|c|c|}
\hline $\begin{array}{l}\text { Patient } \\
\text { no. }\end{array}$ & $\begin{array}{l}\text { Sex; } \\
\text { group }\end{array}$ & $\begin{array}{l}\text { Year of } \\
\text { surgery }\end{array}$ & $\begin{array}{l}\text { Parathyroid and thyroid } \\
\text { surgery performed }\end{array}$ & $\begin{array}{l}\text { Parathyroid } \\
\text { diagnosis }\end{array}$ & $\begin{array}{l}\mathrm{Ca} / \mathrm{s} \\
\text { preop }\end{array}$ & $\begin{array}{l}\mathrm{Ca} / \mathrm{s} \\
\text { postop }\end{array}$ & $\begin{array}{c}\text { Change } \\
(\mathrm{mol})\end{array}$ & $\begin{array}{c}\text { Change } \\
(\%)\end{array}$ & $\begin{array}{c}\mathrm{Ca} / \mathrm{s} 1 \text { st to } \\
\text { 3rd year }\end{array}$ & $\begin{array}{l}\mathrm{Ca} / \mathrm{s} 4 \text { th to } \\
6 \text { th year }\end{array}$ & $\begin{array}{l}\mathrm{Ca} / \mathrm{s} 7 \text { th to } \\
12 \text { th year }\end{array}$ & $\begin{array}{l}\mathrm{Ca} / \mathrm{s} 13 \text { th to } \\
20 \text { th year }\end{array}$ \\
\hline 1 & M III & 1962 & 3 exc/ 3 Pth; opx 2; & $1 \mathrm{Hpl}+1 \mathrm{Ad}$ & 2.75 & 2.53 & 0.22 & 8.0 & - & $2.60-2.65$ & - & - \\
\hline 2 & M III & 1963 & 1 exc (original report lost) & $\mathrm{Ad}$ & 2.85 & 2.45 & 0.40 & 14.0 & 2.50 & $2.75-2.90$ & $2.55-2.65$ & - \\
\hline 3 & $\mathrm{FI}$ & 1967 & 1 exc/ 3 Pth; Thyr-x & $1 \mathrm{Hpl}$ Pth & 2.60 & 2.45 & 0.15 & 5.8 & 2.60 & 2.75 & $2.34-2.42$ & $2.50-2.70$ \\
\hline 4 & F III & 1968 & 1 exc $+1 b / 4$ Pth; H-thyr-x & $\mathrm{Ad}$ & 3.58 & 2.80 & 0.78 & 21.8 & 2.65 & $2.65-2.80$ & - & - \\
\hline 5 & $\mathrm{~F} \|$ & 1968 & 2 exc/ 3 Pth; opx 2; Thyr-x & $\mathrm{Ad}$ & 2.85 & 2.60 & 0.25 & 8.8 & - & 2.62 & - & $2.76-2.90$ \\
\hline 6 & $\mathrm{MI}$ & 1969 & 2 exc/ 4 Pth & $\mathrm{Ad}$ & 2.75 & 2.55 & 0.20 & 7.3 & - & 2.60 & 2.70 & $2.55-2.60$ \\
\hline 7 & F III & 1971 & $3 \frac{1}{2}$ exc/4 Pth; opx 2; H-thyr-x & 3 Hpl Pth & 2.75 & 2.55 & 0.20 & 7.3 & $2.45-2.65$ & - & 2.55 & - \\
\hline 8 & F III & 1973 & 1 exc $+2 \mathrm{~b} / 4$ Pth & $\mathrm{Ad}$ & 3.10 & 2.55 & 0.55 & 17.7 & $2.50-2.70$ & - & - & - \\
\hline 9 & F III & 1973 & 1 exc/ 3 Pth & $\mathrm{Ad}$ & 2.90 & 2.60 & 0.30 & 10.3 & 2.65 & - & - & - \\
\hline 10 & $\mathrm{FI}$ & 1974 & 2 exc $+1 b / 3$ Pth & 3 Hpl Pth & 3.10 & 2.80 & 0.30 & 9.7 & - & 2.80 & $2.60-2.80$ & 2.80 \\
\hline 11 & $\mathrm{Fi}$ & 1975 & 2 exc $+1 b / 4$ Pth & 2 Hpl Pth & 2.68 & 2.45 & 0.23 & 8.6 & 2.65 & - & $2.39-2.45$ & - \\
\hline 12 & M II & 1976 & 2 exc $+1 b / 4$ Pth; & 2 Hpl Pth & 2.99 & 2.47 & 0.52 & 17.4 & $2.53-2.81$ & - & $2.60-2.70$ & - \\
\hline 13 & $\mathrm{FI}$ & 1978 & 2 exc/4 Pth; & $\mathrm{Ad}$ & 2.92 & 2.63 & 0.29 & 9.9 & - & - & $2.60-2.70$ & - \\
\hline 14 & $\mathrm{Fi}$ & 1979 & 1 exc $+3 b / 4$ Pth; Impl; Thyr-x & $\mathrm{Ad}+\mathrm{Impl}$ & 2.95 & 2.44 & 0.51 & 17.1 & 2.60 & - & $2.80-3.10$ & - \\
\hline 15 & $\mathrm{~F} \|$ & 1979 & 1 exc $+1 \mathrm{~b} / 4$ Pth & $1 \mathrm{Hpl} \mathrm{Pth}$ & 2.76 & 2.44 & 0.32 & 11.6 & 2.66 & 2.82 & 2.20 & - \\
\hline 16 & $\mathrm{~F} \|$ & 1981 & 1 exc/4 Pth & $\mathrm{Ad}$ & 2.70 & 2.40 & 0.30 & 11.1 & 2.62 & $2.40-2.60$ & - & - \\
\hline 17 & $\mathrm{FI}$ & 1982 & $1 \mathrm{exc} / 2$ Pth & $\mathrm{Ad}$ & 2.90 & 2.50 & 0.40 & 13.8 & $2.70-2.80$ & $2.60-2.90$ & - & - \\
\hline 18 & $\mathrm{Fi}$ & 1982 & 1 exc/ 4 Pth & $\mathrm{Ad}$ & 2.80 & 2.60 & 0.20 & 7.1 & 2.60 & $2.40-2.80$ & - & - \\
\hline 19 & FI & 1982 & $1 \mathrm{exc} / 4$ Pth & $\mathrm{Ad}$ & 2.80 & 2.40 & 0.40 & 14.3 & 2.70 & $2.55-2.64$ & - & - \\
\hline
\end{tabular}


Table 3 Result of follow-up of 19 consecutive patients left with persistent disease after surgery for primary hyperparathyroidism (HPT). Pathological values are marked $\left({ }^{*}\right)$. $\mathrm{SglD}=$ single-gland disease; MgID = multiple-gland disease. Patients of group I were followed up in Göteborg, those of group II outside Göteborg. The patients of group III were deceased $(\dagger)$ at follow-up in 1986, and for those their last serum calcium $(\mathrm{Ca} / \mathrm{s})$ registration found is given. Hypercalcaemia was graded: $+++/++=$ substantial;

$+=$ mild $/$ moderate; $m=$ marginal; and $\mathrm{no}=$ normocalcaemia. $\mathrm{Ht}=$ hypertension; $\mathrm{CVD}=$ cardiovascular disease; $\mathrm{PTH} / \mathrm{s}=$ serum parathyroid hormone; iPTH = intact parathyroid hormone; Pers = persistent. Blood pressure, given in brackets, was measured at follow-up (mm Hg).

\begin{tabular}{|c|c|c|c|c|c|c|c|c|c|c|c|c|c|}
\hline $\begin{array}{l}\text { Patient } \\
\text { no. }\end{array}$ & $\begin{array}{l}\text { t Sex; } \\
\text { group }\end{array}$ & $\begin{array}{l}\text { Year } \\
\text { of } \\
\text { surgery }\end{array}$ & $\begin{array}{l}\text { Type of } \\
\text { HPT }\end{array}$ & $\begin{array}{c}\text { Total Ca/s } \\
\text { at follow-up } \\
(\mathrm{mmol} / \mathrm{l})\end{array}$ & $\begin{array}{c}\text { Ionised } \\
\text { Ca/s } \\
(\mathrm{mmol} / \mathrm{l})\end{array}$ & $\begin{array}{l}\text { Serum } \\
\text { creatinine } \\
(\mu \mathrm{mol} / \mathrm{l})\end{array}$ & $\begin{array}{c}\text { PTH } / \mathbf{s} \\
\text { RIA } \\
\text { pmol/l) }\end{array}$ & $\begin{array}{l}\text { iPTH/s } \\
\text { IRMA } \\
\text { (ng/l) }\end{array}$ & $\begin{array}{c}\text { Age } \\
\text { (years) }\end{array}$ & $\begin{array}{l}\text { Follow-up } \\
\text { (years) }\end{array}$ & $\begin{array}{l}\text { HPT } \\
\text { status at } \\
\text { follow-up }\end{array}$ & $\begin{array}{l}\text { The patient's own } \\
\text { health description, } \\
\text { and a summary }\end{array}$ & $\begin{array}{l}\text { Ht and } \\
\text { CVD-year of } \\
\text { diagnosis }\end{array}$ \\
\hline 1 & M III & 1962 & MglD & $2.63^{*}$ & - & 120 & - & - & 69 & 4.6 & Pers? Ca: + & $\begin{array}{l}\text { † 1972: skull fracture, intracranial } \\
\text { haemorrhage; backache }\end{array}$ & $\mathrm{Ht}-1962$ \\
\hline 3 & FI & 1967 & SgID & $2.50 / 2.70^{*}$ & 1.29 & 70 & 6.8 & 46 & 74 & 20.1 & Pers $^{\star} \mathrm{Ca}:+$ & $\begin{array}{l}\text { OK, minor malfunction, } \\
\text { anxiety at times }\end{array}$ & $\mathrm{Ht}-1986 ; \mathrm{CVD}-1970$ \\
\hline 4 & F III & 1968 & SgID & $2.65^{*}$ & - & 80 & - & - & 68 & 4.0 & Pers? Ca: + & $\begin{array}{l}\text { †1974: Breast cancer with } \\
\text { metastases; body-pain; fracture } \\
\text { of humerus } 1971\end{array}$ & $\mathrm{Ht}-1965 ; \mathrm{CVD}-1961$ \\
\hline 5 & F II & 1968 & SgID & $2.90^{\star} / 2.76^{*}$ & - & 74 & $175^{*}$ & - & 75 & 17.3 & Pers* Ca: +++ & $\begin{array}{l}\text { - Unwilling to communicate-lived } \\
\text { isolated in a cottage; anxiety }\end{array}$ & $\mathrm{Ht}$ - yes; CVD - yes \\
\hline 6 & M I & 1969 & SgID & $2.60 / 2.55$ & 1.28 & 104 & $11.4^{\star}$ & $72^{*}$ & 75 & 18.1 & Pers* Ca: $\mathrm{m} / \mathrm{no}$ & $\begin{array}{l}\text { Unwell, general bodypain; } \\
\text { backache; anxiety; vertebral } \\
\text { fracture } 1985\end{array}$ & $\mathrm{Ht}-$ for long time \\
\hline 7 & F III & 1971 & MglD & 2.55 & - & 110 & - & - & 77 & 8.0 & Pers? Ca: m/no & $\begin{array}{l}\text { † 1983:; CVD; bodypain; anxiety; } \\
\text { loss of initiative; considered odd }\end{array}$ & $\mathrm{Ht}-1972 ; \mathrm{CVD}-1967$ \\
\hline 8 & F III & 1973 & SgID & $2.50 / 2.70^{\star}$ & - & 100 & - & - & 71 & 0.2 & Pers? Ca: + & $\begin{array}{l}\text { †1976:; CVD; senile dementia; } \\
\text { chronic cystitis }\end{array}$ & $\mathrm{Ht}-1962 ; \mathrm{CVD}-1962$ \\
\hline 9 & F III & 1973 & SgID & $2.65^{*}$ & - & $125^{*}$ & Increased & d - & 68 & 1.0 & Pers* Ca: + & $\begin{array}{l}\text { 1975: cerebrovascular lesion; } \\
\text { gout; Op. malignant tumour } \\
\text { of the colon } 1974\end{array}$ & $\mathrm{Ht}-1973 ; \mathrm{CVD}-$ yes \\
\hline 11 & FI & 1975 & MgID & $2.45 / 2.39$ & 1.25 & 79 & - & $80 *$ & 66 & 11.8 & Pers* Ca: no & $\begin{array}{r}\text { Unwell, anxiety; cardiac angina; } \\
\text { bleeding ulcer } 1984 \text { and } 1986\end{array}$ & CVD - 1974 \\
\hline 12 & M II & 1976 & MglD & $2.60 / 2.60 / 2.70^{*}$ & - & 71 & - & - & 68 & 10.2 & Pers? Ca: + & $\begin{array}{l}\text { OK, minor malfunction; } \\
\text { no medication; cerebrovascular } \\
\text { lesion } 1985\end{array}$ & $\mathrm{Ht}-(160 / 100) ; \mathrm{CVD}-$ yes \\
\hline 13 & FI & 1978 & SgID & $2.60 / 2.60$ & $1.36^{*}$ & 74 & 8.7 & 53 & 74 & 9.1 & Pers* Ca: + & $\begin{array}{l}\text { OK, cardiac angina; hip fractures } \\
1979+1985\end{array}$ & $\mathrm{Ht}-1977 ; \mathrm{CVD}-$ yes \\
\hline 14 & $\mathrm{FI}$ & 1979 & SgID & $3.10^{\star} / 2.90^{*}$ & $1.57^{*}$ & $132^{*}$ & $37.0^{*}$ & $337^{*}$ & 77 & 7.8 & Pers $^{\star}$ Ca: +++ & $\begin{array}{l}\text { - Unwell, dementia; multiple cerebral } \\
\text { infarctions; diabetes } 1982\end{array}$ & $\mathrm{Ht}-1978 ; \mathrm{CVD}-1980$ \\
\hline 15 & $F \|$ & 1979 & SgID & 2.20 & - & 71 & - & - & 72 & 7.0 & Ca: no?/ false? & $\begin{array}{l}\text { Fine, but minor malfunction, } \\
\text { diabetes 1982; cerebrovascular } \\
\text { lesion in 1983 }\end{array}$ & $\mathrm{Ht}-1973 ; \mathrm{CVD}-$ yes \\
\hline 16 & F II & 1981 & SgID & $2.60 / 2.40 / 2.40$ & - & 50 & - & - & 51 & 4.7 & Pers? Ca: m/no & $\begin{array}{l}\text { Fine, medication for hypotension; } \\
\text { dysuria; lower extremity } \\
\text { fracture } 1986\end{array}$ & - \\
\hline 17 & FI & 1982 & SglD & $2.60 / 2.80 * / 2.90^{*}$ & - & 86 & 8.0 & 50 & 79 & 5.1 & Pers ${ }^{\star} \mathrm{Ca}:++$ & $\begin{array}{l}\text { OK, but dysuria, dizziness; in need of } \\
\text { care; slightly senile, no medication }\end{array}$ & $\mathrm{Ht}-(170 / 90)$ \\
\hline 18 & $\mathrm{FI}$ & 1982 & SglD & $2.80 \star / 2.40$ & 1.29 & 73 & -7 & 42 & 60 & 4.2 & Pers* Ca: ++ & OK, anxiety at times & $\mathrm{Ht}-1974$ \\
\hline 19 & $\mathrm{FI}$ & 1982 & SglD & $2.64 * / 2.55$ & $1.32^{*}$ & 81 & 7.7 & 41 & 54 & 5.2 & Pers* Ca: + & $\begin{array}{l}\text { Unwell, anxiety, depression; } \\
\text { cardiac angina }\end{array}$ & $\mathrm{Ht}-1979 ; \mathrm{CVD}-1984$ \\
\hline
\end{tabular}


Table 4 Comparison of state of health of the patients still alive at long-term follow-up after surgery for primary hyperparathyroidism (pHPT) according to a questionnaire; 13 patients with persistent disease vs 509 patients who were surgically cured. Blood pressure measurements were also performed. Two-sided $P$ values are given.

\begin{tabular}{|c|c|c|c|c|c|}
\hline & \multicolumn{2}{|c|}{$\begin{array}{c}\text { Persistent } \\
\text { disease }\end{array}$} & \multicolumn{2}{|c|}{ Cured pHPT } & \multirow[b]{2}{*}{$\boldsymbol{P}$} \\
\hline & $n$ & $\%$ & $n$ & $\%$ & \\
\hline Total number & 13 & - & 509 & - & - \\
\hline History of bone fracture & 4 & $30.8 \%$ & 74 & $14.5 \%$ & 0.2282 \\
\hline I am in excellent health & 2 & $15.4 \%$ & 161 & $31.6 \%$ & $>0.30$ \\
\hline I am in excellent health and without medication & 0 & $0 \%$ & 84 & $16.5 \%$ & 0.199 \\
\hline No hypertension and without cardiovascular medication & 1 & $7.8 \%$ & 200 & $39.3 \%$ & 0.0309 \\
\hline I am troubled by some kind of disorder, worry or anxiety & 10 & $77.0 \%$ & 290 & $57.0 \%$ & 0.0759 \\
\hline Not at all & 3 & - & 219 & - & - \\
\hline Slightly & 1 & - & 71 & - & - \\
\hline Moderately & 7 & - & 165 & - & - \\
\hline Substantially & 2 & - & 54 & - & - \\
\hline My condition, discomfort or illness affects my everyday life & 13 & $100 \%$ & 404 & $79.0 \%$ & 0.0057 \\
\hline Not at all & 0 & - & 105 & - & - \\
\hline Slightly & 1 & - & 157 & - & - \\
\hline Moderately & 7 & - & 144 & - & - \\
\hline Substantially & 5 & - & 103 & - & - \\
\hline I am in frequent need of medical care, and/or have a serious situation & 0 & $0 \%$ & 18 & $3.5 \%$ & $>0.30$ \\
\hline In nursing home & 2 & $15.4 \%$ & 6 & $2.1 \%$ & 0.0295 \\
\hline
\end{tabular}

et al. (5). Mean follow-up time was greater than 10 years in three of these studies $(1,6,12)$, and 8.2 years in one (5). In the remaining it was 3.5-5.6 years $(2-4)$, which might not suffice for forming an opinion. It is well known that signs and symptoms in primary hyperparathyroidism are rarely obvious, that the serum calcium level alone does not fully reflect the degree of disease, and that marginally or moderately increased serum calcium levels may occur even in substantial hyperparathyroidism $(5,13-15)$. In a few of the follow-up studies mentioned above it was briefly reported that the patients were well $(2-4)$. Mean age in these reports were only 50.8, 59.8 and 54.8 years respectively, which might explain this observation. But Van't Hoff et al. (3) also observed, in 22 hyperparathyroid patients who were not advised operation, that ten patients, mostly elderly, suffered from cardiovascular disease, which was not at that time considered related to their hyperparathyroidism, but was the grounds not to recommend surgery.

In the present patient series, $2.1 \%$ of the patients were left with persistent hyperparathyroidism, as compared with $1.3 \%$ reported by Bruining et al. in 1981 (16), and 3.7\% by Lundgren et al. in 1992 (17). To the best of our knowledge, no long-term follow-up with detailed comparison of the clinical status of patients with persistent hyperparathyroidism and patients with cured disease has been performed previously, which may depend just on the fact that the numbers of patients with persistent disease are generally small. The answers in the questionnaires of the present study were equally collected and interpreted for all 522 patients studied in this perspective, making comparison of the subgroups reliable irrelevant of their size. We found that the state of health was described as significantly better by the patients with cured hyperparathyroidism as compared with the ones with persistent disease. The finding of congruity between the results of the eight tests performed makes significance by chance unlikely; the difference was significant in three tests, a strong trend in one, and insignificant in four tests. The cured patients had marginally longer follow-up time and also slightly higher mean preoperative serum calcium levels, which factors therefore could not have produced these test results. Nor could the difference in age between the two groups explain the present findings, as it was statistically insignificant. An insignificant relationship would not be expected to indirectly produce a highly significant difference between other possibly related variables.

The risk of needing extensive surgery was $2.0 \%$ in our patient series. If a higher cure rate had been aimed at, the number of patients needing extensive surgery would probably have been higher. Mediastinal explorations will, however, always be necessary from time to time, and in our patient series it had to be done in at least 12 patients, or in $1.4 \%$ of them, the conclusion of which is that not more than about $98 \%$ of the patients with primary hyperparathyroidism could be expected to be cured by neck surgery alone. Van Heerden et al. (18) reported in 1991 a corresponding success rate after primary neck exploration of $98.2 \%$ in a consecutive series of 379 patients.

In summary, in our patient series, 18 patients, or $2.0 \%$, needed extensive surgery for cure of their primary hyperparathyroidism. Another 19 patients, or $2.1 \%$, were left with persistent disease. Their serum calcium and creatinine levels had with few exceptions remained stable at long-term follow-up, but these patients had generally cardiovascular morbidity. The 
state of health of 13 of these patients who were still alive at follow-up was unsatisfactory in comparison with that of the patients who had been successfully surgically treated for primary hyperparathyroidism. Therefore the result of this study supports surgical treatment of primary hyperparathyroidism. It demonstrated, in contrast to previous reports on the subject, that persistent primary hyperparathyroidism ought not to be evaluated on the basis of laboratory data alone.

\section{Acknowledgements}

This study was supported by grants from funds of Sahlgrenska Hospital for research on cardiovascular diseases, and $\mathrm{G}$ and $\mathrm{M}$ Lindgrens donation. We thank all colleagues who took care of and examined these patients at Sahlgrenska Hospital, and especially Dr I Hedman, Dr L-E Tisell, Dr B- $\AA$ Bengtsson, Dr G Hansson, Nurse G Widell and Secretary B-I Gunnarsson for their valuable help in collecting patient data.

\section{References}

1 Scholz DA \& Purnell DC. Asymptomatic primary hyperparathyroidism, a 10-year prospective study. Mayo Clinic Proceedings $198156473-478$.

2 Rohl PG, Wilkinson M, Clifton-Bligh P \& Posen S. Hyperparathyroidism, experiences with treated and untreated patients. Medical Journal of Australia 1981 1 519-521.

3 Van't Hoff W, Ballardie FW \& Bicknell EJ. Primary hyperparathyroidism: the case for medical management. British Medical Journal 1983287 1605-1608.

4 Posen S, Clifton-Bligh P, Reeve TS, Wagstaffe C \& Wilkinson M. Is parathyroidectomy of benefit in primary hyperparathyroidism? Quarterly Journal of Medicine, New series $1985 \mathbf{5 4} 241-251$.

5 Corlew DS, Bryda SL, Bradley EL III \& DiGirolamo M. Observations on the course of untreated primary hyperparathyroidism. Surgery 198598 1064-1071.

6 Palmér M, Jakobsson S, Åkerström G \& Ljunghall S. Prevalence of hypercalcemia in a health survey: a 14-year follow-up study of serum calcium values. European Journal of Clinical Investigation $19881839-46$.

7 Hedbäck G, Tisell L-E, Bengtsson B-Å, Hedman I \& Odén A. Premature death in patients operated on for primary hyperparathyroidism. World Journal of Surgery 199014 829-836.

8 Hedbäck G \& Odén A. Recurrence of hyperparathyroidism, a longterm follow-up after surgery for primary hyperparathyroidism. European Journal of Endocrinology 2003148 383-488.

9 Lehman EL. Testing Statistical Hypotheses, edn 1, ch 3.5, pp 78-83. New York: John Wiley \& Sons, 1959.

10 Maxwell AE. Analyzing Qualitative Data, pp 63-72. London: Methuen, 1961.

11 Hedbäck G \& Odén A. Cardiovascular disease, hypertension, and renal function in primary hyperparathyroidism. Journal of Internal Medicine $2002251476-483$.

12 Palmér M, Bergströlm R, Åkerström G, Adami H-O, Jakobsson S \& Ljunghall S. Survival and renal function in untreated hypercalcaemia. Lancet 1987 i 59-62.

13 Siperstein AE, Shen W, Chan AK, Duh Q-Y \& Clark OH. Normocalcemic hyperparathyroidism, biochemical and symptom profiles before and after surgery. Archives of Surgery $1992 \quad 127$ 1157-1163.

14 Burney RE, Jones KR, Peterson M, Christy B \& Thompson NW. Surgical correction of primary hyperparathyroidism improves quality of life. Surgery $1998 \mathbf{1 2 4} 987-992$.

15 Talpos GB, Bone HG III, Kleerekoper M, Phillips ER, Alam M, Honasoge $\mathrm{M}$ et al. Randomized trial of parathyroidectomy in mild asymptomatic primary hyperparathyroidism: patient description and effects on the SF-36 health survey. Surgery $2000 \mathbf{1 2 8}$ 1013-1021.

16 Bruining HA, van Houten H, Juttman JR, Lamberts SWJ \& Birkenhäger JC. Results of operative treatment of 615 patients with primary hyperparathyroidism. World Journal of Surgery $1981585-90$.

17 Lundgren E, Rastad J, Ridefelt P, Juhlin C, Åkerström G \& Ljunghall S. Long-term effects of parathyroid operation on serum calcium and parathyroid hormone values in sporadic primary hyperparathyroidism. Surgery 1992112 1123-1129.

18 Van Heerden JA, Hon MB \& Grant CS. Surgical treatment of primary hyperparathyroidism: an institutional perspective. World Journal of Surgery 199115 688-692.

Received 31 January 2003

Accepted 14 October 2003 